\title{
Two new species of Spadicoides from Brunei and Hong Kong
}

\author{
W. H. $\mathrm{Ho}^{1}$ \\ Yanna \\ Kevin D. Hyde \\ Centre for Research in Fungal Diversity, Department of \\ Ecology and Biodiversity, The University of Hong \\ Kong, Pokfulam Road, Hong Kong SAR, China
}

\begin{abstract}
Spadicoides hodgkissa sp. nov. and Spadicoides arengae sp. nov., recorded from submerged decaying wood in Hong Kong and from decaying palm fronds in Brunei, are described and illustrated. Spadicoides hodgkissa is characterized by versicolored, obovoid conidia with up to 2 septa, including a distal distoseptum and a proximal euseptum, while Spadicoides arengae is characterized by unicellular, ellipsoidal conidia with verruculose walls that are relatively large. Eight genera, including Dendrographium, Helminthosporium, Luzfridiella, Paliphora, Polyschema, Polytretophora, Porosubramaniania, and Weufia, have the same conidiogenesis as Spadicoides. A key to these genera is provided.
\end{abstract}

Key Words: freshwater fungi, palm fungi, polytretic conidiogenesis, taxonomy, tropical fungi

\section{INTRODUCTION}

In a continuing study of freshwater (Ho et al 1999a, Hyde et al 1999) and palm fungi (Yanna et al 2000) in the tropics, an undescribed dematiaceous hyphomycete was found on wood baits of Pinus massoniana Lamb. submerged in a small stream in Hong Kong and another on decaying fronds of $A r$ enga undulatifolia Becc. in Brunei. These fungi produce macronematous, mononematous conidiophores, polytretic, integrated conidiogenous cells, and acropleurogenous, solitary, obovoid to ellipsoidal conidia. Critical examination of the morphological characters suggested placement in the genus Spadicoides.

The genus Spadicoides was erected by Hughes (1958) to accommodate a single species, S. bina (Corda) S. Hughes. Taxa producing conidia with solitary or catenate conidia on branched or unbranched co-

Accepted for publication July 27, 2001.

${ }^{1}$ Corresponding author, Email: wellcomeho@hotmail.com nidiophores were included in Spadicoides or Diplococcium. The catenation of conidia is considered taxonomically more important than the branching of conidiophores, and thus the generic description of Spadicoides was emended to include taxa producing solitary conidia on branched or unbranched conidiophores, whereas Diplococcium includes taxa producing catenate conidia (Sinclair et al 1985). The teleomorph of Spadicoides is unknown.

The species of Spadicoides collected in Hong Kong and Brunei differ from the described species and are therefore described as new.

\section{TAXONOMY}

Spadicoides hodgkissa W. H. Ho, Yanna et K. D. Hyde, sp. nov. FIGS. 1-12

Coloniae effusae, atro-brunneae, pilosae. Mycelium partim in substrato immersum, ex hyphis pallide brunneis, septatis, laebus, ramosis, 3-4 $\mu \mathrm{m}$ crassis compositum. Conidiophora macronemata, mononemata, erecta, solitaria, non ramosa, recta vel leniter flexuosa, laevia, crassitunicata, multiseptata, $60-120 \times 3.5-4 \mu \mathrm{m}$, ad basim 4.5-6 $\mu \mathrm{m}$ lata, atro-brunnea, apicem versus pallidiora. Cellulae conidiogenae polytreticae, in conidiophoris incorporatae, terminales et intercalares. Conidia acropleurogena, solitaria, versicoloria, obovoidea, guttulatae, unicellularia $(5 \times 3 \mu \mathrm{m})$, 1-euseptatae vel 2-septatae $(9-13$ $\times 5-8 \mu \mathrm{m})$; cellulae distalia crassitunicatae, olivaceae brunneae; cellulae basilare tenuitunicatae, pallide brunneae vel hyalinae, cum hilo.

Colonies on decaying wood effuse, dark brown, hairy (FIGS. 1, 2, 9). Mycelium partly immersed in the substrata, composed of pale brown, septate, smoothwalled, branched hyphae, 3-4 $\mu \mathrm{m}$ wide. Conidiophores macronematous, mononematous, erect, solitary, unbranched, dark brown, paler towards the apex, straight or slightly flexuous, smooth, thick-walled, multiseptate, $60-120 \times 3.5-4 \mu \mathrm{m}(\bar{x}=82 \times 3.8 \mu \mathrm{m}$, $\mathrm{n}=25$ ), occassionally swollen at the apex, slightly swollen, 4.5-6 $\mu \mathrm{m}$ at the base (FIGs. 3-5, 10). Conidiogenous cells polytretic, integrated, terminal and intercalary, with pale colored pores remaining at the conidiogenous loci (FIGs. 3, 4, 11). Conidia acropleurogenous, solitary, versicolored, obovoid, smooth, guttulate, unicellular $(5 \times 3 \mu \mathrm{m})$, 1-euseptate or 2 septate $(9-13 \times 5-8 \mu \mathrm{m} ; \bar{x}=11.8 \times 7 \mu \mathrm{m}, \mathrm{n}=25)$ comprising a proximal euseptum and a distal distoseptum (FIGS. 6-8, 12); distal distosepta possess a con- 

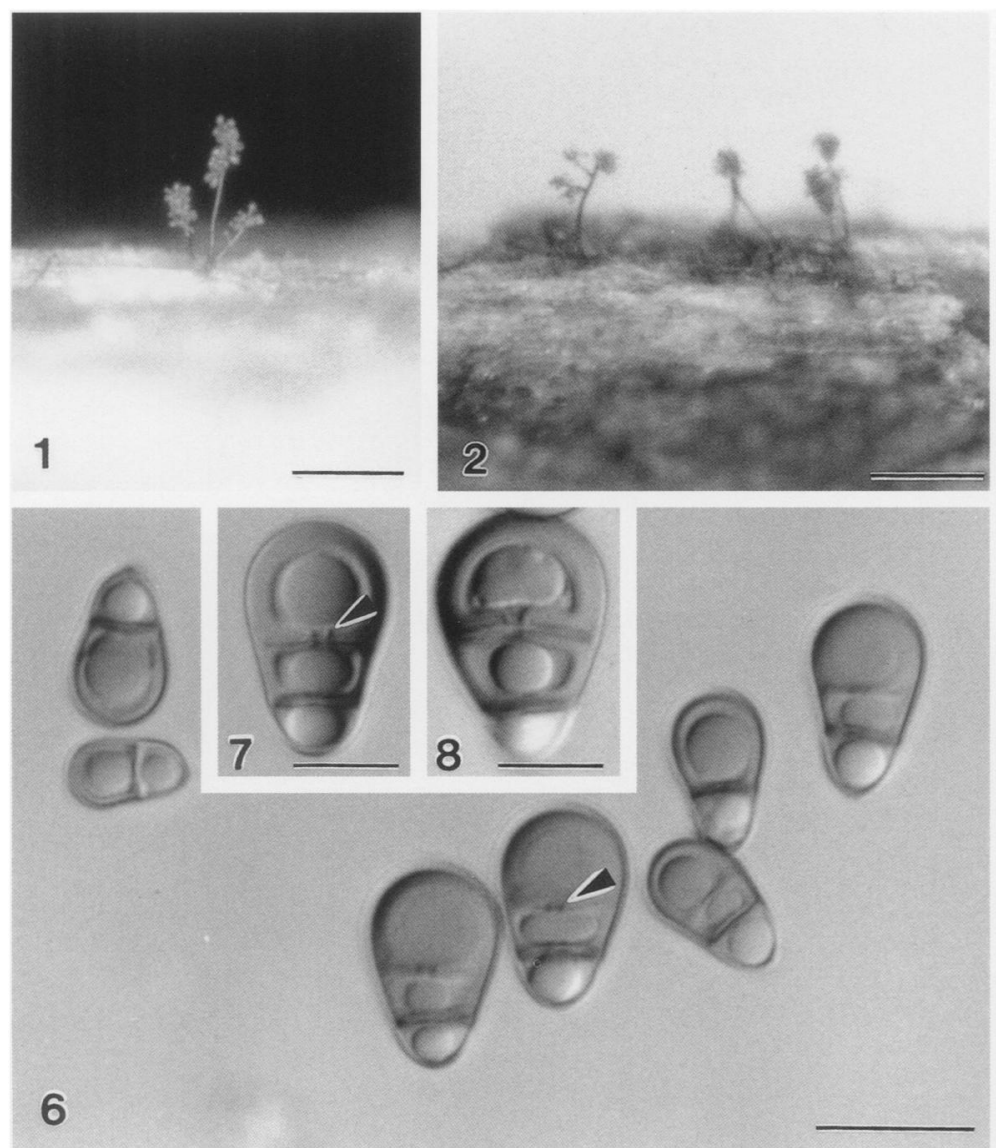

FIGS. 1-8. Spadicoides hodgkissa (from HOLOTYPE). 1, 2. Colonies on woody substrata. 3. Apex of a conidiophore with pale colored pores. 4. Conidiogenous locus in conidiogenous cell. 5. Conidiophore attached to remains of substratum. 6-8. Conidia with 1 or 2 septa. Note the distal septa are distoseptate with a conspicuous central pore surrounded by a pigmented ring (arrowed). Scale bars: $1,2=100 \mu \mathrm{m}, 3,4,7,8=5 \mu \mathrm{m}, 5,6=10 \mu \mathrm{m}$.

spicuous central pore which is surrounded by a pigmented ring, appearing as dolipores in side view; distal cells thick-walled, olivaceous brown; basal cells thinwalled, very pale brown or hyaline, with a small hilum at the base.

Etymology. In honor of Prof. Sir I. John Hodgkiss who has promoted ecological and biodiversity studies in Hong Kong since 1968.

Material examined. CHINA. HONG KONG: Tai Po Kau Forest Stream, wood baits of Pinus massoniana, 28 Jun 1997, W. H. Ho WH3O7 [HKU(M) 6155, HOLOTYPE]; 29 Dec 1996, W. H. Ho Eे S. Y. Ho [HKU(M) 5965].

Spadicoides arengae W. H. Ho, Yanna et K. D. Hyde, sp. nov. Figs. 13-18

Coloniae effusae, atro-brunneae, pilosae. Mycelium partim in substrato immersum, ex hyphis pallide brunneis, septatis, laevibus, ramosis, 2-3.5 $\mu \mathrm{m}$ crassis compositum. Conidiophora macronemata, mononemata, erecta, solitaria, non ramosa, brunnea, apicem versus pallidiora, recta vel leniter flexuosa, laevia, tenuitunicata, multisepata, 210-400 $\times 3.5-4 \mu \mathrm{m}$, ad basim 5-6 $\mu \mathrm{m}$ lata. Cellulae conidiogenae polytreticae, in conidiophoris incorporatae, terminales et intercalares. Conidia acropleurogena, solitaria, unicellularia, ellipsoidea, 11-18 $\times 4-6 \mu \mathrm{m}$, pallide brunneae, aguttulatae, verruculosae, cum hilo.

Colonies on decaying palm frond effuse, dark brown, hairy (FIG. 13). Mycelium partly immersed in the substrata, composed of pale brown, septate, smooth-walled, branched hyphae, 2-3.5 $\mu \mathrm{m}$ wide. $\mathrm{Co}$ nidiophores macronematous, mononematous, erect, solitary, unbranched, brown, paler towards the apex, straight or slightly flexuous, smooth, thin-walled, multiseptate, $210-400 \times 3.5-4 \mu \mathrm{m}(\bar{x}=312 \times 3.7$ $\mu \mathrm{m}, \mathrm{n}=25$ ), slightly swollen, $5-6 \mu \mathrm{m}$ at the base (FIGs. 14, 17). Conidiogenous cells polytretic, integrated, terminal and intercalary, with pale colored pores remaining at the conidiogenous loci after conidial secession (FIGS. 15, 18). Conidia acropleurogenous, solitary, unicellular, ellipsoidal, 11-18 $\times 4-6 \mu \mathrm{m}(\bar{x}$ $=15.2 \times 5.6 \mu \mathrm{m}, \mathrm{n}=25)$, very pale brown, nonguttulate, wall verruculose, with a small hilum at the base (FIGS. 16, 19). 

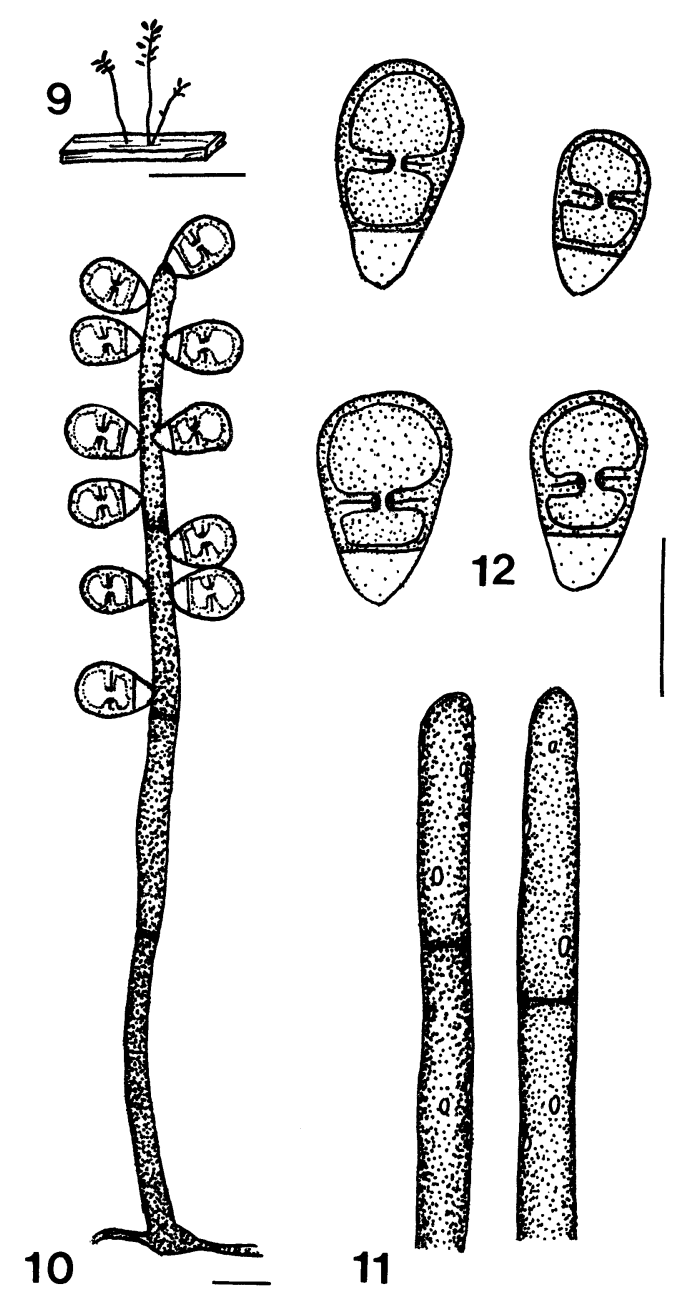

11
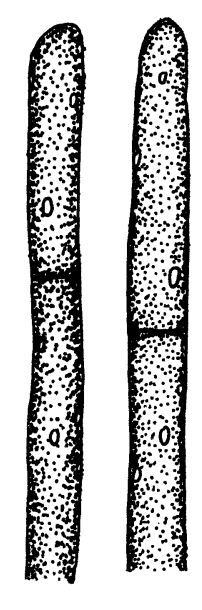

FIGS. 9-16. Schematic diagrams. 9-12. Spadicoides hodgkissa. 9. Colony on substratum. 10. Conidiophore. 11. Apex of conidiophores illustrating conidiogenous loci. 12. Conidia. 13-16. S. arengae. 13. Colony on substratum. 14. Conidiophore. 15. Apex of conidiophores illustrating conidiogenous loci. 16 . Conidia. Scale bars: $9,13=100 \mu \mathrm{m}, 10-12,14-16=10 \mu \mathrm{m}$.

Etymology. In reference to the host Arenga undulatifolia.

Material examined. BRUNEI DARUSSALAM. TEMBURONG: Batu Apoi Forest Reserve, The University of Brunei Darussalam Kuala Belalong Field Studies Centre (KBFSC), Baki Tributary, on decaying rachis of Arenga undulatifolia, 13 Dec 1998, Yanna (Yan75Ar, HOLOTYPE).

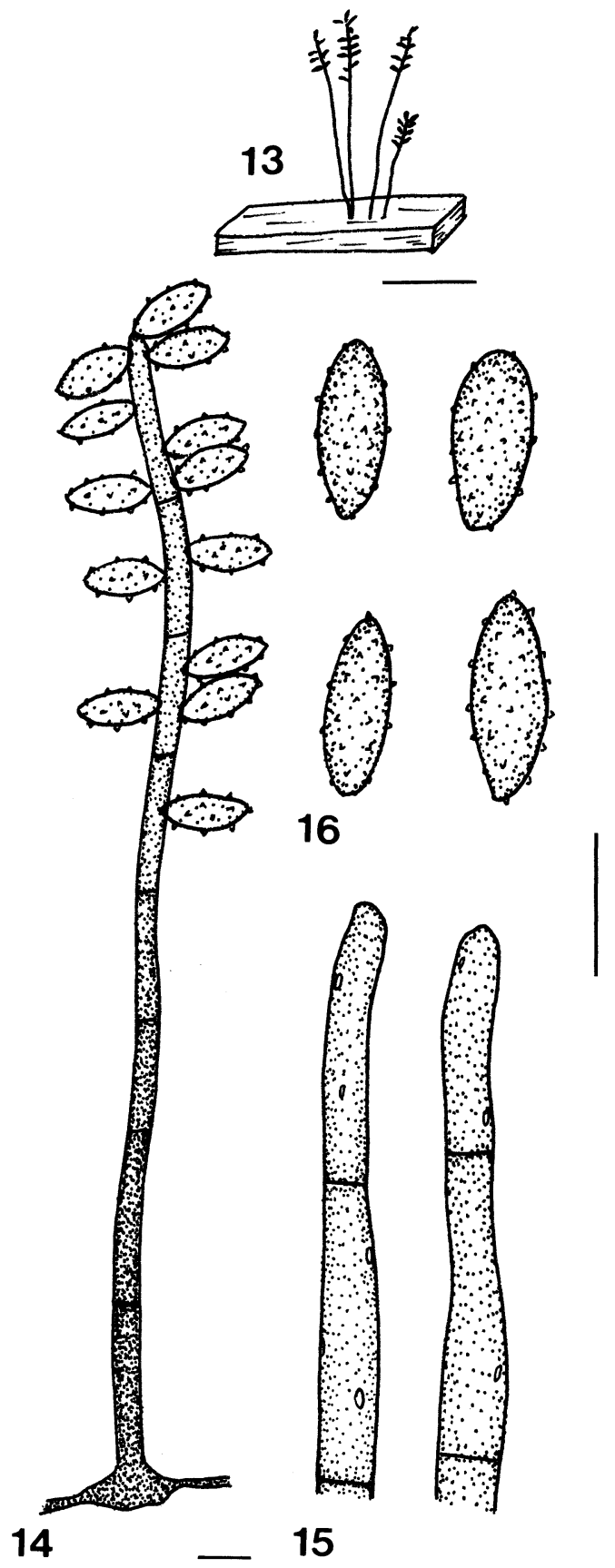

14 

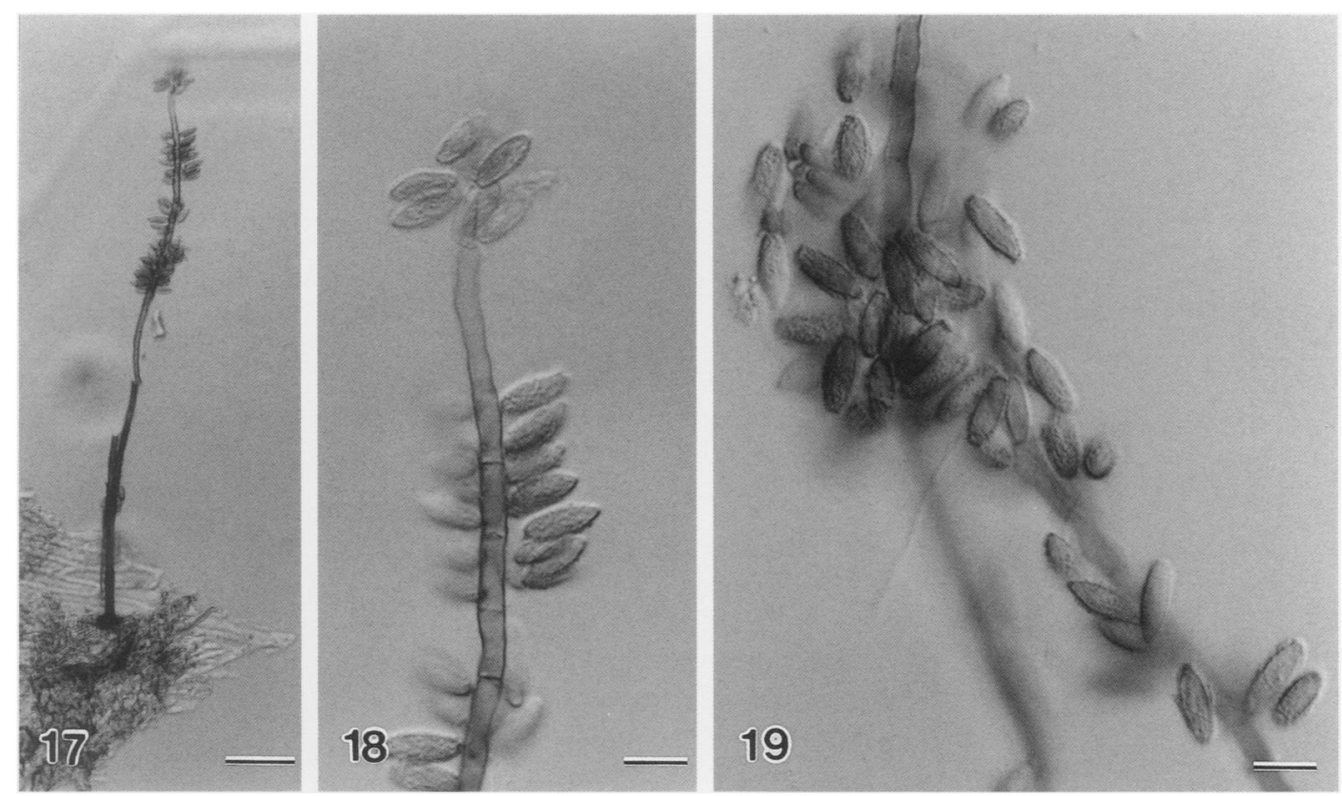

FIGS. 17-19. Spadicoides arengae (from HOLOTYPE). 17. Conidiophore attached to remains of substratum. 18. Apex of a conidiophore with conidia attached. 19. Conidia. Scale bars: $17=50 \mu \mathrm{m}, 18,19=10 \mu \mathrm{m}$.

D. Hyde and S. obclavata var. heterocolorata R. F. Castañeda, Guarro \& Cano (Castaneda et al 1997, Goh and Hyde 1998). The later was elevated to species rank as S. heterocolorata (R. F. Castañeda, Guarro \& Cano) Goh \& K. D. Hyde (Goh and Hyde 1998).

Spadicoides hodgkissa is similar to S. macroobovata and $S$. obovata in producing 2-septate, obovoid conidia, and similar to $S$. cordanoides, S. cubensis, S. curvularioides, S. heterocolorata, S. klotzschii, S. macroobovata, S. obclavata, S. obovata, and $S$. subramanianii in producing versicolored conidia (Goh and Hyde 1996). Spadicoides hodgkissa is distinct in producing conidia, each with a proximal euseptum and a distal distoseptum. Other species of Spadicoides do not produce distoseptate conidia.

In Spadicoides hodgkissa, the distal distoseptum of conidia has a conspicuous central pore, surrounded by a pigmented ring (FIGS. 7, 8). Ho (1998) listed 46 mitosporic fungi producing conidia with pigmented ring at the central septal pore, including 30 producing distoseptate conidia and 16 producing euseptate conidia. Janetia curviapicis Goh \& K. D. Hyde is similar to Spadicoides hodgkissa in producing conidia with both types of septa, and the pigmented rings are restrictively found on the distosepta (Goh and Hyde
1996). This pigmented ring can be a generic feature [e.g., all species of Canalisporium possess this structure (Goh et al 1998)], or a specific feature [e.g., only some species of Digitodesmium possess this structure (Ho et al 1999b)].

Spadicoides arengae resembles $S$. verrucosa in producing unicellular conidia with verruculose wall, but differs in conidial size $(11-18 \times 4-6 \mu \mathrm{m}$ vs $4-5.5 \times$ 2-3 $\mathrm{mm})$. Spadicoides afzeliae, S. aggregata, S. carpatica, S. cordanoides, S. curvularioides, and S. palmicola also produce conidia with verruculose wall, but all have septate conidia. Spadicoides arengae resembles $S$. atra in producing unicellular ellipsoidal conidia, but differs in conidial size and wall ornamentation (Goh and Hyde 1996, 1998).

Eight other genera also produce solitary conidia from polytretic conidiogenous cells with several conidiogenous loci in each of the conidiogenous cells (Hawksworth et al 1995). A key to these genera and Spadicoides is presented.

Isolation of Spadicoides hodgkissa and S. arengae on water agar was attempted using single spore isolation technique (Choi et al 1999). The conidia of both species did not germinate after one month. Their teleomorphs are not known.

\section{KEY TO SPADICOIDESLIKE GENERA}

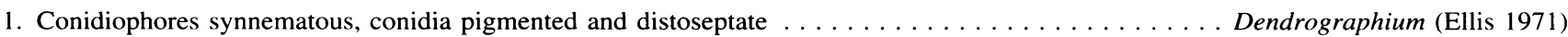

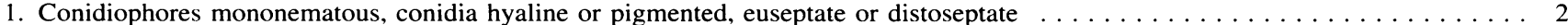

2. Conidiophores in fascicles, conidia pigmented and euseptate . . . . . . . . . Luzfridiella (Castañeda and Kendrick 1991)

2. Conidiophores solitary, conidia hyaline or pigmented, euseptate or distoseptate $\ldots \ldots \ldots \ldots$

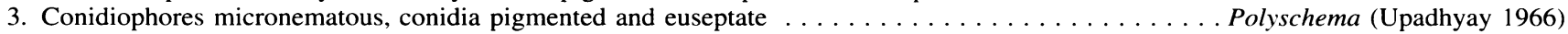

3. Conidiophores macronematous, conidia hyaline or pigmented, euseptate or distoseptate $\ldots \ldots \ldots \ldots$ 
4. Conidia with curved, pigmented basal cells and cylindro-truncate, hyaline apical cells . . . . . . . . . . . . $\ldots \ldots \ldots \ldots \ldots \ldots \ldots \ldots \ldots \ldots \ldots \ldots \ldots \ldots$ Polytretophora $(=$ Parahelminthosporium)(Mercado Sierra 1983)

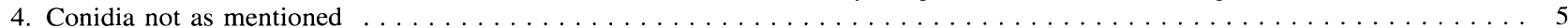

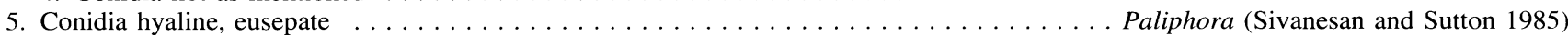

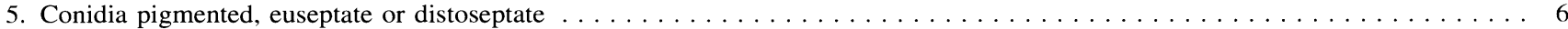

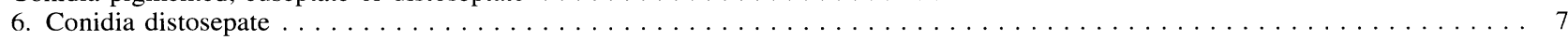

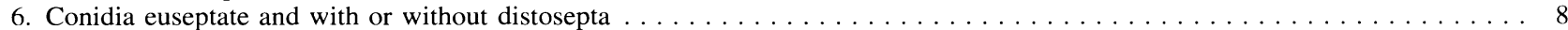

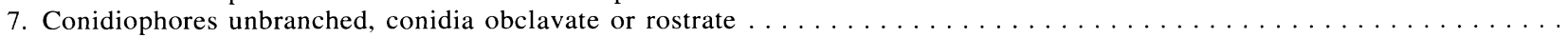

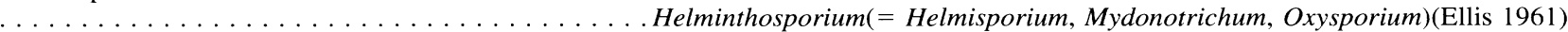

7. Conidiophores branched at the apex, conidia V-shaped ..............Weufia $(=$ Granmamyces $)($ Bhat and Sutton 1985)

8. Conidia euseptate, conidiogenous loci cicatrized . . . . . . . . . . . . . . . Porosubramaniania (Holubová-Jechová 1985)

8. Conidia euseptate or with both eusepta and distosepta, conidiogenous loci not cicatrized . . . . . . . Spadicoides (Hughes 1958)

\section{ACKNOWLEDGMENTS}

We would like to thank The University of Hong Kong for the award of Post-doctoral Fellowship and Post-graduate Studentship. Ho would like to thank Prof. I.J. Hodgkiss for his supervision. This study is partly supported by the Industrial Department of the Government of Hong Kong SAR $(\mathrm{AF} / 59 / 98)$.

\section{LITERATURE CITED}

Bhat DJ, Sutton BC. 1985. New and interesting hyphomycetes from Ethiopia. Trans Br Mycol Soc 85:107-122.

Castañeda RF, Guarro J, Cano J. 1997. Notes on conidial fungi. XII. New or interesting hyphomycetes from Cuba. Mycotaxon 63:169-181.

- Kendrick BW. 1991. Ninety-nine conidial fungi from Cuba and three from Canada. Univ Waterloo Biol Ser 35:1-132.

Choi YW, Hyde KD, Ho WH. 1999. Single spore isolation of fungi. Fungal Divers 3:29-38.

Ellis MB. 1961. Dematiaceous hyphomycetes III. Mycol Pap 82:2-21.

- 1971. Dematiaceous hyphomycetes. Kew, England: CAB International. 608 p.

Goh TK, Ho WH, Hyde KD, Whitton SR, Umali TE. 1998. New records and species of Canalisporium (Hyphomycetes), with a revision of the genus. Can J Bot 76:142152.

— Hyde KD. 1996. Spadicoides cordanoides sp. nov., a new dematiaceous hyphomycete from submerged wood in Australia, with a taxonomic review of the genus. Mycologia 88:1022-1031.

- - 1998. Spadicoides palmicola sp. nov. on $\mathrm{Li}^{-}$ cuala sp. from Brunei, and a note on Spadicoides heterocolorata comb. nov. Can J Bot 76:1698-1702.
Hawksworth DL, Kirk PM, Sutton BC, Pegler DN. 1995. Ainsworth and Bisby's dictionary of the fungi. 8th ed. CAB International, U.K. 616 p.

Ho WH. 1998. Biodiversity, ecological and ultrastructural observations of fungi on wood submerged in tropical streams. [PhD Dissertation]. Hong Kong: The University of Hong Kong. 229 p.

- Hyde KD, Hodgkiss IJ. 1999a. Ultrastructure of Annulatascus aquaticus sp. nov., a freshwater ascomycete on submerged wood from Hong Kong. Fungal Divers 2:119-128.

$\longrightarrow,-1$ 1999b. Digitodesmium recurvum, a new species of chirosporous hyphomycete from Hong Kong. Mycologia 91:900-904.

Holubová-Jechová V. 1985. Porosubramaniana, new genus of lignicolous Hyphomycetes. Proc Indian Acad Sci Pl Sci 94:253-258.

Hughes SJ. 1958. Revisiones hyphomycetum aliquot cum appendice de nominibus rejiciendis. Can J Bot 36:727836.

Hyde KD, Ho WH, Tsui KM. 1999. The genera Aniptodera, Halosarpheia, Nais and Phaeonectriella from freshwater. Mycoscience 40:165-183.

Mercado Sierra A. 1983. Nuevos e interesantes hifomicetes enteroblasticos de Cuba. Acta Botanica Cubana 16:1-8.

Sinclair RC, Eicker A, Bhat DJ. 1985. Branching in Spadicoides. Trans Br Mycol Soc 85:736-738.

Sivanesan A, Sutton BC. 1985. Microfungi on Xanthorrhoea. Trans Br Mycol Soc 85:239-255.

Upadhyay HP. 1966. Soil fungi from North-East Brazil. II. Mycopathol Mycol Appl 30:276-286.

Yanna, Ho WH, Goh TK, Hyde KD. 2000. A new species of Everhartia, associated with leaf spots of Phoenix hanceana from Hong Kong. Bot J Linnean Soc 134:465470. 